\title{
Strategies for internationalisation of SMEs - based on the example of the company operating in the creative industries sector
}

\begin{abstract}
Monika Fabinska*
The modern global economy exerts tremendous pressure on the development and functioning of every business. Technological evolution facilitates penetration of markets, customers demand higher quality for a lower price, a new generation of aggressive competitors emerges, and global companies demand high competitiveness - these are only few features of the global market. The analysed company has a stable position in the domestic market and it must enter foreign markets in order to grow and increase its competitiveness. Internationalisation is a natural step in the development of any successful business. The aim of the paper is (i) to conduct an analysis of the target markets (FMCG, pharmaceuticals, and advertising services) in selected Scandinavian countries and (ii) to develop recommendations for optimum instruments to facilitate the entry into the target markets in selected countries: Sweden and Norway.
\end{abstract}

Keywords: internationalisation, internationalisation strategy, Scandinavian markets, FMCG market, pharmaceutical market, creative industries.

Submitted: 06.05.17 | Accepted: 08.03.18

\section{Strategie internacjonalizacji firmy rodzinnej na przykładzie sektora kreatywnego}

Wspótczesna globalna gospodarka wywiera ogromna presję na rozwój i funkcjonowanie każdej firmy, w tym firm rodzinnych. Ewolucja technologiczna utatwia penetrację rynków, klienci wymagaja wyższej jakości za niższa cenę, pojawia się generacja nowej bardzo agresywnej konkurencji, firmy w zasięgu globalnym narzucaja wysoka konkurencyjność - to tylko nieliczne cechy globalnego rynku. Analizowana firma rodzinna ma ustalona pozycję na rynku krajowym i aby rozwijać się i zwiększać konkurencyjność, musi wchodzić na rynki zagraniczne. Celem artykułu jest 1) analiza rynków docelowych (FMCG, farmaceutyka, oraz ustug reklamowych) w wybranych krajach skandynawskich oraz 2) wypracowanie rekomendacji w zakresie optymalnych narzadzi wejścia przez firmę rodzinna na wskazane rynki docelowe (FMCG, farmaceutyka, oraz ustug reklamowych) $w$ wybranych krajach: $w$ Szwecji $i$ Norwegii.

Słowa kluczowe: internacjonalizacja, strategia internacjonalizacji firm rodzinnych, rynki skandynawskie, rynek FMCG, rynek farmaceutyczny, sektory kreatywne.

Nadesłany: 06.05.17 | Zaakceptowany do druku: 08.03.18

JEL: L25, L26

\footnotetext{
Monika Fabińska, PhD - Department of Entrepreneurship and Industrial Policy, Faculty of Management, University of Lodz.

Correspondence address: Department of Entrepreneurship and Industrial Policy, Faculty of Management, University of Lodz, Jana Matejki St. 22/26, 90-237 Lodz; e-mail: fabinska@uni.lodz.pl.
} 


\section{Introduction}

The modern global economy exerts tremendous pressure on the development and functioning of every business. Technological evolution facilitates penetration of markets, customers demand higher quality for a lower price, a new generation of aggressive competitors emerges, and global companies demand high competitiveness - these are only some features of the global market (Figueira-de-Lemos, Johanson and Vahlne, 2011). The analysed company has a stable position in the domestic market and it must enter foreign markets in order to grow and increase its competitiveness. Internationalisation is a natural step in the development of any successful business (Cieślik, 2011; Rymarczyk, 2004). The industry in which the analysed company operates is generally dominated by competition with a global reach, therefore in order to maintain its market position, the company should focus on internationalisation by exporting its services. Benefits of export are undisputed. Export helps to make better use of the company's production capacity, and thus increase its profitability (Rymarczyk, 1996; BrojakowskaTrząska, 2016). Export contracts often lead to an increase in the scale of production, services and company development, as they allow to exceed the local market capacity. Presence in international markets allows companies to gain accurate knowledge of their competition and changes occurring in the industry, as well as to improve innovativeness (Głód, 2014). Export increases the customer base and makes companies less dependent on fluctuations in their domestic market. The company's strategy of internationalisation is aimed at preparing market analyses and indicating marketing activities which will determine the direction of its export expansion. The export is not only manner of internationalisation the business activity but for SME's is still the most convince and easy manner of start to penetrate the foreign market (Schweizer, Vahlne and Johanson, 2010). Export is a strategic and long-term decision, therefore, the company must be sure that the main aspects of export activity have been taken into account in the decision-making process. This cannot be a random decision. Export operations require expenditure and a strategy to gain new markets. In the era of global economy, markets are changing very dynamically and competition is constantly growing. Export brings a number of benefits to every company, provided that the company is prepared to export (PlutaOlearnik, 2014).

The aim of the paper is: (i) to conduct an analysis of the target markets (FMCG, pharmaceuticals, and advertising services) in selected Scandinavian countries and (ii) to develop recommendations for optimum instruments to facilitate the entry into the target markets in selected countries: Sweden and Norway.

The choice of the company was dictated by the possibility of internecialization of SMEs on the example of an advanced organizational structure. The company was selected as part of the research carried out in the project "Strategic analysis of enterprises" realized by Regional Association of Private Employers of the Lodz and cofinancing within the convenience of Operation Program Knowledge, Education and Development. As research has shown, not many SMEs from the Lodz region undertake activities related to internationalization.

\section{The analysis of the market position of the company operating in the creative industries sector in terms of the target markets selected for its internationalisation strategy}

Companies operating in the creative industries sector and engaged in the provision of services in the area of advertising products are divided into several segments. These include importers that use internationally produced goods, manufacturers that produce various types of gadgets, such as lanyards, promotional clothing, or memory sticks, and advertising agencies that offer products from Polish and foreign producers or importers. The analysed company's position approximates that of advertising agencies. The company, however, seeks to design gadgets primarily dedicated to individual marketing activities of its customers and produce them without intermediaries. A direct contact, advice and understanding of customer needs (Figure 1 presents the business model of the analysed company) play a very large role in this area. 
Figure 1. The business model of the analysed company
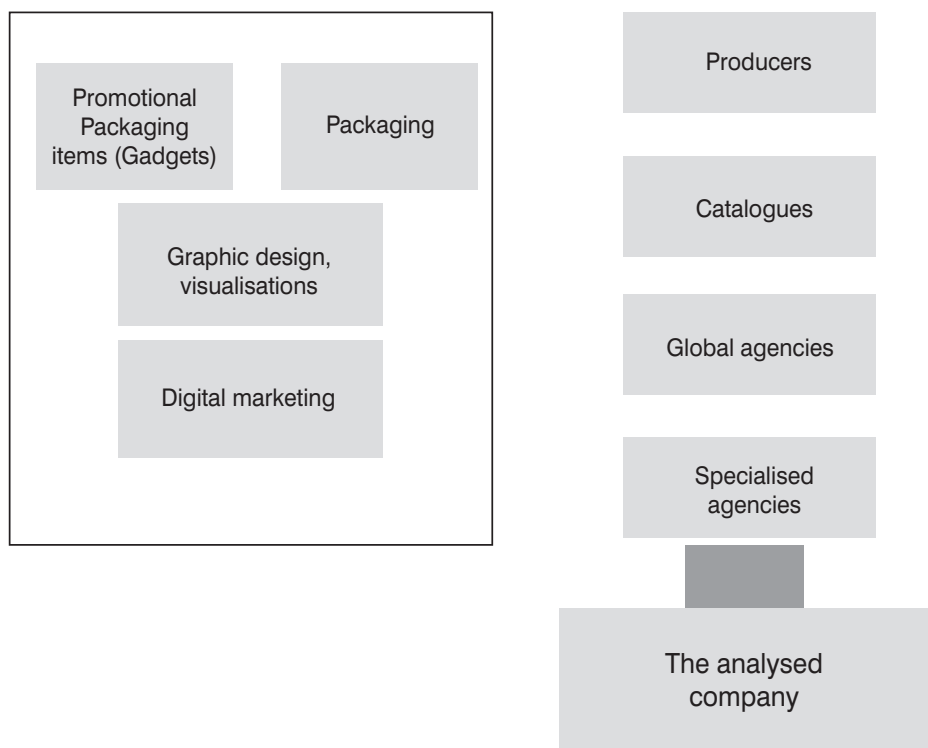

Source: the author's own elaboration based on an interview conducted with the owner of the company.

The countries towards which the analysed company intends to direct its activities in the field of internationalisation include selected Scandinavian countries: Sweden and Norway. The target markets of activities conducted in the field of internationalisation encompass: (i) the FMCG market; (ii) the pharmaceutical market; (iii) the advertising services market.

The internal market in Sweden is a buyer's market. In their actions, Swedes place emphasis primarily on imports, wholesale and retail sales. Sweden is largely dependent on imports, which amount to approx. 7,500 USD per capita. Despite this fact, the country has a foreign trade surplus - the export value is approx. $30 \%$ higher than the import value. Moreover, Sweden is the richest Nordic country and also the most industrialised one (Wai and Noichangkid, 2012).

The market of food products, whose $70 \%$ is dominated by three corporations (ICA, COOP and AxFood Group,) is an example of strong trade concentration. The remaining $30 \%$ is covered by companies whose average annual turnover keeps increasing each year.

Due to the fact that food products constitute more than $70 \%$ of the market, the country invests in small local shops, which constitute the largest group of shops in Sweden. In addition, according to the
Polish-Swedish Chamber of Commerce: seasonally adjusted household consumption, i.e. analysed in the same periods (for the purpose of this study on a quarterly basis), increased by $0.8 \%$ between December 2015 and January 2016. From November 2015 until January 2016, consumption increased by $0.4 \%$ compared to the period from August to October 2015. And in January 2016, household consumption increased by further 2\% (Central Statistical Office of Sweden, 2017).

It should be pointed out that Swedes are very demanding consumers, accustomed to certain standards, and virtually none of them will purchase a product that is not marked with the Swedish label or flag. This is referred to as consumer patriotism. It should be noted that food prices in Sweden do not decrease despite the gradual emergence of new supermarkets from Europe. The food market is still monopolised by a few large actors. Competition on an equal footing is also prevented by the protectionist policy of the government (Wai and Noichangkid, 2012).

Another aspect is the Swedish population's approach to organic food. Swedes are a nation that for the most part eats in a healthy manner. Organic food shops keep opening, arise great interest and have a quite high annual turnover. Sales 
of organic food in grocery shops have increased in Sweden by $11 \%$ in 2010 . This was $3.1 \%$ of the total turnover of food products in the Swedish market. According to the EkoWeb bulletin, in the current year, sales of organic food in grocery shops of this country should increase by a further 10-11\% (Bryała, Lenarcik, Ocieszek et al., 2014).

In contrast to the Swedish market, the structure of the Norwegian retail food market is oligopolistic. The market consists of a large number of small grocery shops which have gradually integrated into large networks that currently have an almost $100 \%$ market share. The networks with the largest annual turnover of more than $90 \%$ of the retail market in Norway include (the order based on their market share) (Wai and Noichangkid, 2012):

- NorgesGruppen;

- Rema 1000;

- ICA.

There are approx. 4,000 food network shops in the Norwegian market. Household consumption in the area of food, beverages and cigarettes grows depending on the current needs of consumers. It should be noted that Norway is a country whose main income is derived from fishing. Due to its direct access to the sea, the fishing industry is growing quickly and is the second largest export sector in Norway after the sale of oil and gas. It includes the traditional sale of fish, fish farming and processing of all kinds of seafood (Data from the Statistical Office of Norway, 2017).

Moreover, Norwegian consumers, as well as consumers in other Nordic countries, are characterised by the ability to pay higher prices for products of their native brands. For many years, there has been little interest among the Norwegians in foreign food. Moreover, the level of prices of foodstuffs offered in Norwegian shops is very high (in 2014 average prices of food products and beverages in Norway were about $77 \%$ higher than the average for the EU countries). The fact that Norway imposes periodic import duties on agrifood goods, protecting its market, is also quite significant (Data from the Statistical Office of Norway, 2017).

In addition, in the last year, the average debt per capita of an adult Norwegian significantly increased in households of Norway, amounting to approx. 6\%. This, in turn, translates into a reduction in consumption of all market goods and services (Data from the Statistical Office of Norway, 2017).

Therefore, most of the income of inhabitants is absorbed by home loans, as well as energy and water bills. In addition, food prices have been rising steadily in Norway: in 2016 the food basket was $230 \%$ more expensive than, for example, in Poland, while prices of foodstuffs in the European Union remain unchanged or increase only slightly. Price differences concern mainly basic goods, such as dairy products or meat (Wai and Noichangkid, 2012).

The analysis of the pharmaceutical market in Scandinavia shows that medications sold in Norway are imported, however, there is a group of Norwegian producers of pharmaceuticals, namely (Data from the Statistical Office of Norway, 2017):

- Nyegaard \& Co A/S (Nyco);

- A/S Apothekernes Laboratorium for Specialpræparater (A.L);

- A/S Farmaceutisk Industri (AFI);

- Weiders Farmasøytiske A/S (Weifa).

The main suppliers of medicines and medical technology are multinational companies. More than $90 \%$ of the pharmaceutical market in Norway belongs to multinational companies represented by their Norwegian branches (Data from the Statistical Office of Norway, 2017).

In Norway, there are local as well as network pharmacies where over the counter and prescription medicines can be bought.

In Sweden, until recently, state-owned pharmacies - the monopolist Apoteket AB - dominated. Now Swedes are in the process of introducing reforms to allow the opening of private pharmacies in order to to improve services and lower prices. In 2011, the first Internet pharmacy was set up (Wai, Noichangkid, 2012).

$99 \%$ of the pharmaceutical industry in Sweden consists of pharmacies where prescription drugs and over the counter ones can be purchased. In addition, in Sweden pain medication (not containing paracetamol) and OTC can be purchased at supermarkets and petrol stations.

Analysing sales of chemical and pharmaceutical products on the Swedish and Norwegian market, a definite increase in sales in Norway can be noted (Data from the Central Statistical Office of Sweden, 2017, Central Statistical Office of Norway, 2017). 
In the analysed markets, there are various advertising agencies, however, none of them offers such a business model and cooperation with the customer within the calculated unit cost as the analysed company. From the point of view of the client, it is a customised product, unique and creative, that meets the marketing needs of the customer in the best way. That is what characterises the company's activity - a comprehensive approach to innovation management within the scope of the services provided.

\section{The company's activities in the target markets planned in the framework of its internationalisation}

Analysing the studied company's activities and activities of companies operating in international markets, it can be said that the manner in which an offer is assessed by customers is virtually the same. The company's offer is evaluated by the national and international client in terms of meeting global standards, consistent with expectations present throughout the European market. The European market is similar culturally and socially. Promotional materials fulfil similar expectations and respond to similar attitudes of consumers shaped by the common European market. At the same time, the model of communication used by multinationals, realised also through the communication channel of advertising materials, is relatively uniform in all the European countries. The fact that purchase processes take place primarily in local markets is a limitation faced by the analysed company. Thus, purchases in international markets often take place outside of Poland - in other countries - that need to be reached with the offer. In addition, purchases and deliveries of goods used in supranational activities are carried out in those countries where corporation head offices are located, which means that the volume of orders is much higher than the one realised in Poland.

In the area of designing labels and packaging, the assumptions of the analysed company are that for large international corporations maintaining consistent graphic communications is an essential element of building marketing communications and brand strength. Changes may concern only the nuances related to local markets. In the case of the Nordic markets, it was necessary to learn design principles specific to those markets, described by their common philosophy.

Command of foreign languages is necessary for better communication within the framework of activities aimed at the new markets. Knowledge concerning the behaviour of final clients in the target markets is also important. Customers expect from the company advice on the selection of the best tools, as well as designing the best gadgets and packaging for a given market. Hence, there is a need for regularly conducted market research. In this case, it can be assumed that recipients of the company's services throughout the European Union have similar attitudes with respect to marketing, hence there are similar possibilities of its impact. Greater volatility, however, should be assumed for the Scandinavian markets.

Therefore, the boundary conditions of promotional tools used in the target markets must be subject to a thorough analysis. Detailed adjustment of the company's offer to the specific requirements of customers in each market is a process which can be implemented in the framework of signed cooperation agreements and which is based on the transfer of knowledge between the company employees implementing the project and its recipient - the customer.

Norway is characterised by a high level of TV ads. The communications market in Norway is very inspiring, although it refers primarily to TV and radio commercials. In Norway, unlike Sweden or Denmark, there are no professional food fairs and promotion of food products is based solely on leaflets or shop catalogues. However, it should be noted that the citizens of this country are accustomed to a fairly high level of marketing campaigns in the media. Advertising budgets are relatively high, and marketing departments avoid "interfering" with the work of advertising agencies, which has a very positive influence on the overall effect of these campaigns. People in Norway clearly like high quality ads which are aimed at inspiring the recipient. Being pushy is not part of the Norwegian c.

The advertising market in Norway is subject to very restrictive regulations concerning street advertisements. As a result, local towns are free from tons of billboards 
and banners placed in violation of architectural conventions. This is also a country that uses its national assets in advertising campaigns.

In the advertising market in Sweden, especially in the FMCG sector, the choice of communication channel is closely related to the seasons, for example, the November and December period brings a peak of promotional activities concerning beverages and desserts. While selecting a marketing communication channel for Swedish consumers, one must analyse in detail daily newspapers, as they cover more than $70 \%$ of advertising in this market. Professional magazines and leaflets, which are usually delivered directly to homes, are also important media. One cannot forget about the Internet, as $80 \%$ of Sweden's population in 2006 used this medium, which means that the country ranks high among the other EU countries in its use. TV commercials, as well as advertising in cinemas, do not arise great interest.

Speaking of marketing communication in the food sector, one cannot forget about trade fairs which are popular in the Swedish market. A number of examples can be provided, two of the most popular trade fairs are listed below.

1. Fastfood \& Café fair, where all trends, ideas, products, and services connected with the fast food and coffee market can be found, has been held in Stockholm since October 2007. The fair has been organised for 10 years and each year $10 \%$ more interested people participate in the event. More than 300 exhibitors present their goods during the fair.

2. GastroNord - is a fair which has also been organised in Sweden for a long time and has enjoyed particular interest of visitors. GastroNord is the largest Scandinavian trade fair of products and catering services for restaurants. The number of exhibitors reaches even 700. The fair is addressed to owners and employees of hotels, restaurants, caterers, cafés and bakeries. The fair is intended exclusively for professionals.

\section{Conclusions}

The studied company is planning to expand the export of promotional items and packaging design services, as well as to begin selling its products and services in the analysed target markets in Scandinavia, i.e.: Sweden and Norway. The company's strategy encompasses the expansion to foreign markets which will contribute to the growth of its foreign trade turnover. The analysed company operates in the sector of $\mathrm{B} 2 \mathrm{~B}$ products and its ultimate client is always another company. Most managers operating in $\mathrm{B} 2 \mathrm{~B}$ markets argue that traditional marketing does not work in sales for the business sector, hence one must use individual marketing solutions, different from the ones employed in consumer markets. The analysed company operates in the sector of advertising that responds to any kind of economic crises. Most companies seek cost savings and "cut" spending on advertising. Therefore, the adoption of a strategy aimed at diversification of market segments and product recipients will help maintain stability and increase the company's turnover.

The main objective of the project is to increase the level of the company's foreign trade through the development of a relevant business model. This business model is to be a tool to gain a share in the analysed markets.

A professional market analysis as well as understanding and adapting the offer to the client in the long term (over 3 years) will greatly affect the development of the company through an increase in turnover from trade and services in international markets and through an increase in the company's share in international markets. The strategic objectives which the analysed company should achieve in the Scandinavian market in the short-and long-term are presented below. For each objective, the measure and the tool to achieve it have been assigned.

I. Scandinavia (Sweden and Norway)

Objectives:

1. Increasing knowledge and skills of the company's employees in the area of purchasing habits and needs of inhabitants of the Scandinavian countries (consumer patriotism).

2. Improving the entry strategy into the markets with very restrictive conditions related to advertising.

3. Making use of the competitive advantage in the form of specialised advice in the area of promotional items and packaging. 
Measures:

1. The number of employees and the level of knowledge and skills acquired within the framework of organised sessions of training in customer service, purchasing needs of inhabitants of the Nordic countries and their legislation.

2. The number of observations made by customers regarding compatibility of the solution with the applicable legislation.

3. A percentage share of the sales of promotional items and packaging in the Scandinavian market. Tools:

1. Training conducted by external experts within the framework of cooperation with the Polish-Swedish Chamber of Commerce.

2. CRM reports.

3. Presentations at trade fairs and exhibitions in the Nordic countries, e.g.: in the course of GastroNord.

\section{References}

Brojakowska-Trząska, M. (2016). Internacjonalizacja polskich przedsiębiorstw. Zarządzanie. Teoria i Praktyka, 1(15), 9-16.

Bryała, M., Lenarcik, J., Ocieszek, G., Okularczyk, M. and Wyra, M. (2014). Branża spożywcza w Szwecji. In: Strategia rozwoju firm branży spożywczej na rynkach zagranicznych. Warszawa: Collect Consulting Sp. z o.o.
Cieślik, J. (2011). Internacjonalizacja mtodych innowacyjnych firm. Warszawa: Polska Agencja Rozwoju Przedsiębiorczości.

Data of the Central Statistical Office of Norway (2017). http://www.ssb.no/en/ (30.03.2017)

Data of the Central Statistical Office of Sweden (2017). http://www.scb.se/ (30.03.2017)

Figueira-de-Lemos, F., Johanson, J. and Vahlne J.E. (2011). Risk management in the internationalization process of the firm: A note on the Uppsala model. Journal of World Business, 46(2), 143-153.

Głód, W. (2014). Internacjonalizacja w procesie rozwoju małych i średnich przedsiębiorstw - wybrane wyniki badań empirycznych. Studia Ekonomiczne, 184, 80-92.

Pluta-Olearnik, M. (2014). Marketing a internacjonalizacja usług - podejścia badawcze. Marketing i Rynek, 8, 601-606.

Rymarczyk, J. (1996). Internacjonalizacja przedsiębiorstwa. Warszawa: Polskie Wydawnictwo Ekonomiczne.

Rymarczyk, J. (2004). Internacjonalizacja i globalizacja przedsiębiorstwa. Warszawa: Polskie Wydawnictwo Ekonomiczne.

Schweizer, R., Vahlne, J.E. and Johanson, J. (2010) Internationalization as an entrepreneurial process. Journal of International Entrepreneurship, 8(4), 343-370.

Wai, H.H. and Noichangkid, P. (2012). The internationalization of born-global SMEs in Northern Sweden: A network perspective. Umeå: Umeå School of Business. 